\title{
Gender Equality in Education: Case of MajorUrbanizing Areas of Pakistan
}

\author{
Hamna Nasir ${ }^{1}$, Ambreen Fatima and Shaista Alam ${ }^{2}$
}

\begin{abstract}
The main purpose of this study is to estimate the effect of gender equality in education and explore its determinants in 14 major cities of Pakistan (rapidly urbanizing) after taking into account the socio-economic indicators (like mother education, household income, household living conditions, etc.). Data is gathered from Pakistan Social Standard Living Measurement Survey (PSLM) from 2004-05 to 2012-13. Pseudo Panel technique is applied using cities and females in age group 15-65 as cohorts. Fixed effect technique is used for analyzing the issue. The results of this study indicates that mother's education, education of the male head of the household, facilities available in the house and income of the household have considerably favorable impact on the education attainment of females.
\end{abstract}

Key Words: Gender Inequality; Education; Socio-economic Profile; Pseudo Panel; Urbanizing Areas and Poverty.JEL Classification: I32, I24, J16, Z130, C33

\section{INTRODUCTION}

"Education is the most powerful weapon you can use to change the world"

(Nelson Mandela)

The minimum goal of education is often considered as training for earning livelihood. The maximum goal of education is socialization, diffusion of knowledge, values, attitudes and norms, required for playing best moral roles in society. In a healthy system of education both goals must be realized. Therefore without investment in education nations cannot be developed. An essential role for the choice of profession is due to education and training which affects individual earnings. By investing in human capital, economic and social opportunities are improved and it helps in reducing poverty and foster technical progress. Economic involvement, child transience, fertility, individual health and greater speculation in the refinement and wellbeing of upcoming generations have direct effects on education.

The goal is achievable only if making education attainment necessary for every individual especially making it mandatory for women, an educated girl of today will become a mother of futures educated and responsible young generation, a number of trickle down benefits are associated with gender base education. One of the benefits is reduced fertility rate and hence population growth will slow down. Educated women prefer having fewer children and invest more on human capital formation of the children. Also they can provide better care and nutrition for their children which results in a reduction in probability of catching diseases and child mortality rate. It could also be said that benefits of girl's education ends up with a healthier next generation. By investing in higher education of girls, yields to high dividends. However, learning achievement is dependent on the socio economic status (SES) of the household they belong too.

The acquirement of social status is by social position and money or economy a person is affiliated with his economic status. The issues such as progenitor's edification, employment, revenue and amenities offered to juvenile are characterized as home environment. Educational attainment is directly linked to their parent's education. Female progenitor's erudition is more significant than the male progenitor's erudition because an educated mother has greater affect in household decision making which may permit her to secure more

\footnotetext{
${ }^{1}$ Corresponding author is an M.Phil Student at Applied Economics Research Centre, University of Karachi. The Email ID: hamnainfinite@gmail.com. Postal Address: Applied Economics Research Centre, University of Karachi. Phone No: 0331-2183074
}

\footnotetext{
${ }^{2}$ Associate Professors at Applied Economics Research Centre, University of Karachi. amber aerc@yahoo.com

shaista.aq@gmail.com
} 
resources for her children. Moreover if an educated mother participates in the labor force, she may pay some additional educational expenses and will be aware of her children's progress. By having fewer children she may be able to give more attention to her each child.

In Pakistan low educational progress and high dropout rate is the result of low female educational attainment. Education system of Pakistan after 65 years of independence is still under developed. Indicators show dismal performance of the education sector: extremely stunned levels of adult articulacy, fewer admission and huge dropout rates at the elementary level, high learner-instructor ratios, ample gender and provincial disparities, and low levels of public asset. In Pakistan, gender discrimination is evident all around the country. Only 10\% of Pakistani women have received 10 years or more of schooling. Pakistani women often lack access to basic education facilities. Female literacy rate is about $\mathbf{4 1 \%}$ as compared to male literacy rate of $\mathbf{6 9 \%}$ (PSLM 2012-13).The low literacy of females is due to many reasons, families with less income and more number of children educate male as he is considered to support his family. Girls' access to education in Pakistan has been confined. Despite enhancements in the last 20 years, underlying factors still make the state education system unproductive and must be addressed if girls' access to education is to be ensured. The current male to female literacy ratio is still at 65:40. (http://www.eldis.org/).

In Pakistan major factors responsible for the substandard female's education is lack of educational facilities. Moreover the issues that hinder enrolment rates of young women include poverty, cultural restrictions, illiteracy of progenitors and parental concerns about security and mobility of their daughters. Society's emphasis on girl's modesty, safety and early marriages may limit family's willingness to send them to school. Most of the Pakistani young women remain unlettered due to deprivation of fundamental edification and training opportunities. In traditional societies females are discouraged to pursue education by their parents/elders because they are considered suitable only for domestic responsibilities and to take care of the younger offspring. Female education is deprived due to old norms; rituals, classification of status, rural society and erroneously implicated pious information. Low worth of female instruction is perceived by their procreators because the crucial supervision positions in provincial and nationwide life are restricted to men only. Most families prohibit sending their girls to coeducation institute for higher studies as well. Even though women have acquired higher education, but still general admission of female juveniles in primary and secondary institutions is lesser than male juveniles.

The education attainment by gender in different provinces at Primary, Secondary and Tertiary level is depicted below in Table 1:

Table 1: Education Attainment at Various Levels (\%)

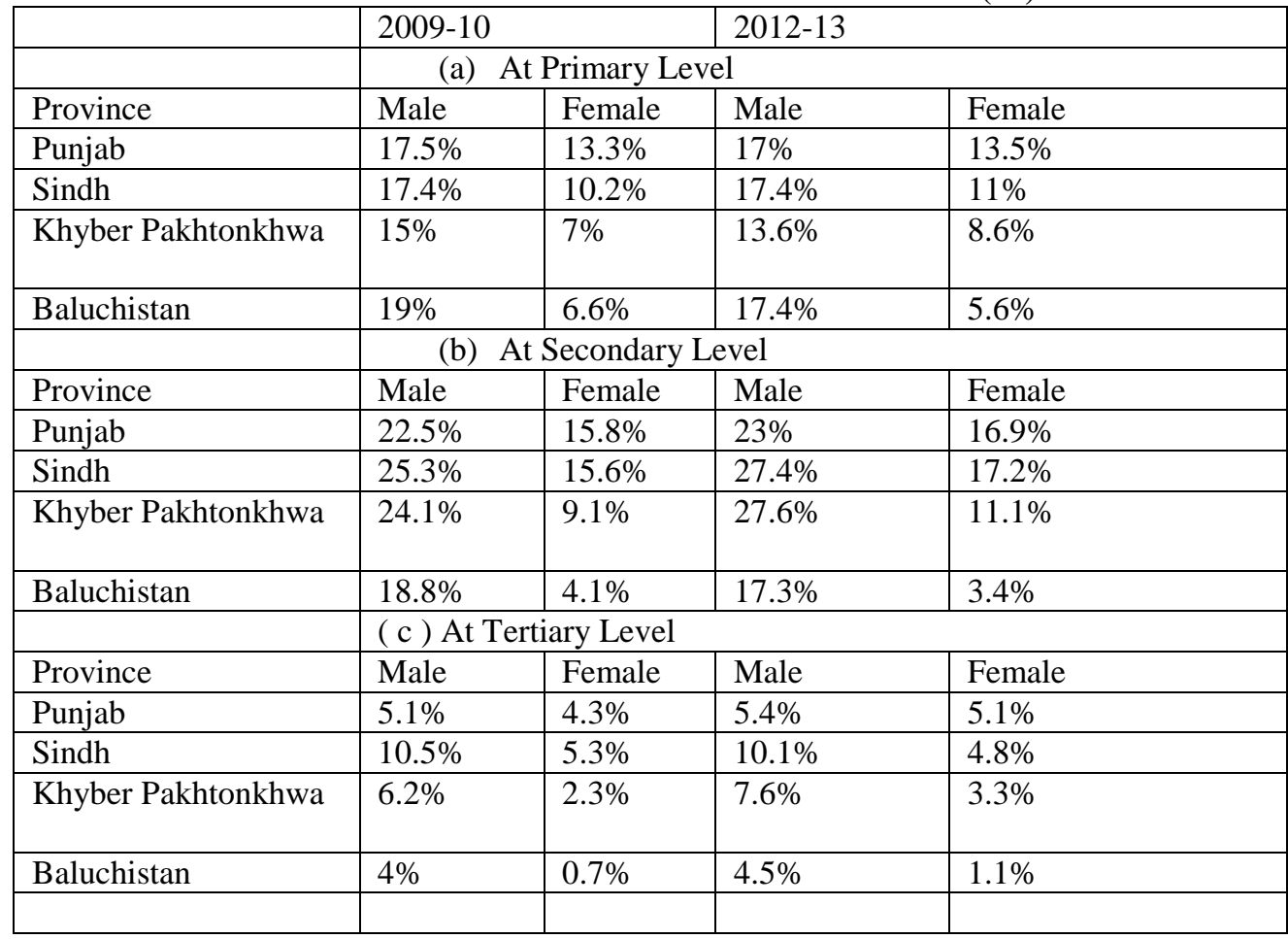

Source: Labor force survey (LFS) 2009-10 and 2012-13

It can be analyzed that education attainment at the primary level for males have remained $17 \%$ for all provinces except Khyber Pakhtonkhwa, whereas it has slightly increased for females except Baluchistan. Table 1(b) 
depicts that secondary education attainment of males and females have increased in all provinces except Baluchistan whereas tertiary education attainments of males and females have increased in all provinces except in Sindh. The data of Literate population shows that in urban and rural areas males are more literate than females. It is also evident from table 2 that learned people are more in cities in contrast to rustic areas.

Table 2: Literate Population 10 years and above (\% of the population age 10 years and older)

\begin{tabular}{|l|l|l|l|l|}
\hline City & Urban & Female & Male & Female \\
\hline & Male & 86 & 82 & 72 \\
\hline Islamabad & 95 & 79 & 90 & 70 \\
\hline Rawalpindi & 91 & 78 & 70 & 57 \\
\hline Lahore & 85 & 75 & 70 & 54 \\
\hline Faisalabad & 81 & 79 & 61 & 39 \\
\hline Karachi & 87 & 70 & 61 & 35 \\
\hline Hyderabad & 77 & 62 & 58 & 22 \\
\hline Sukkur & 84 & 53 & 66 & 32 \\
\hline Peshawar & 80 & 58 & 74 & 28 \\
\hline Quetta & 88 & & & \\
\hline
\end{tabular}

Source: PSLM 2012-13

The present study endeavors to explore the current situation of gender equality that exists in Pakistan. As gender disparity is usually considered rooted in the rural areas so we have not included these traditional cultural based areas as unit of investigation. This study is focus on the rapidly urbanizing areas of Pakistan only by arguing that gender disparity with the time is near to abolish from metropolitan areas as compared to rustic areas. The analysis not only provides the estimate of gender equality across cities but also across time.

The main objective of the present study is to estimate the gender equality of education from primary to post graduation (16 years of education) across city and time through Education Equality Index (EEI) for the major cities of Pakistan. EEI is a part of Gender Related Development Index ${ }^{3}$ (GDI).

EEI is defined in Human Development Index (HDI) of Education by UNDP. For estimation of EEI adult literacy index and education attainment index at all levels of education for males and females are calculated separately.

The secondary objective of this study is to estimate the factors determining gender equality at different levels of education, after taking into account the socio economic indicators. The socio economic factor explored includes household size, number of children under 15, mother's education; gender of the head of household and his/her education, household income, household living conditions which include facility of drinking water, gas as a source of cooking, etc. Decision made by the head of household, mother's education and household income are also important factors for the education attainment especially of female. This paper is organized as follow: section 2 presents brief review of relevant studies, section 3 consists of assessment methodology of education equality index and theoretical framework to estimate determinants of education equality index. Data sources and econometric methodology are discussed in sections 4 and 5 respectively. The empirical results are displayed in section 6. Conclusion and policy implications are presented in Section 7.

\section{LITERATURE REVIEW}

Many studies have been conducted at national and international level concerning gender inequality in education. Literature review of some related studies is presented below.Jennifer (2005) emphasizes between the correlation of Socio economic status and home environment and further argues that the quality of life of a student is dictated by his/her socioeconomic status. The edifying level of the begetters', particularly the female begetter's education is more important to influence students than the encouragement of teachers'. It was discovered that for the aspiration of students the civilized and economic variables occupy an essential task and the predictive power of them to attend university increase significantly.

In most of the developed public Schools are free, municipalities offer compulsory and upper secondary level education free for individuals aged 20 and above and tertiary level education is generally available in the cities free of cost. Knodel and Jones (1997) also established maximum gender discrepancies in Thailand and Vietnam among households with low income. They further confirm that awareness of begetters' has improved for sending their female descendants to centre of learning than their male descendants.

\footnotetext{
${ }^{3}$ To gauge the inequalities between men and women GDI is utilized. Equally distributed life expectancy index, education index and income index are used to estimate GDI.
} 
Three major socioeconomic determinants of household requirement for academics are identified by Schultz (1999) i.e.: "public expenses on education, education of the parents, and assets of the family". Sundaram (2000) collected the sample of Indian districts for his study for 1981 and found that as the accessibility of training précised by educators for each youngster increases, the gender disparity in knowledge among juveniles' aged 10 to 14 declines. Schnabel (2002) found for the data of Germany and US, association between edification and SES of begetters and the edifying and proficient victory of their descendants.Procreators' erudition and procreators' revenue are significant determinants of education which were determined by Tansel (2003) for Turkey and Al-Qudsi (2003) for Kuwait, Jordan, Gaza, and Yemen. Holmes, (2003) shows the influence of gender differences on parent's education, as educated father encourages their male descendants to take higher education so is the case with educated mothers who allow their female descendants to study.

Hassink and Kiiver (2007) used the micro data of Germany. Instrumental variable regression was used to evaluate the fundamental consequences of progenitor's instruction and revenue of a household on institutional accomplishment of an adolescent at two points in time of his academic career. Firstly, due to lower parental involvement the School performance will certainly change without going as far as imposing a switch in school types. Second, the German educational system determines the division of samples, and cannot be freely chosen. For the children of secondary school types around the age of 10-12 parental involvement in Germany is high, but afterwards it declines. It is indicated by the results that during the education household income has momentous implementation on instructive achievement of progenies while the parents' edification seems to be stable. Lochner and Belley (2008) find that the post-secondary (PS) attendance (and attendance at four-year PS institutions) for U.S which, even after controlling for analogous computation of family environment and youth cognitive triumph which was positively related to procreators revenue. The results of this study show that procreators revenue and PS attendance relationship is constructive, but considerably dismal in Canada. EngirDemir (2008) found for students with low performance in school was due to low SES and poor backgrounds. In Turkey an intellectual level of the procreators particularly the male procreators play an essential role in students' academic performance. Mono parental families' or progenitors who are not possessors of dwelling, the performance of these students are academically enhanced. The outcomes of the survey carried in Turkey proclaims that the school performance of the students do not affect household size and the number of siblings. Erlendsdóttir (2010) found in Namibia at Combretum Trust School that the students' academic achievement is positively affected by parental involvement. These findings suggest that nurturing and supportive home environment approaches to triumphant learners. Irrespective of age, socioeconomic surroundings, and cultural and native conditions, the parental involvement affects students' educational attainment.

According to Bowden and Doughney (2011) progeny who seek higher education have an advanced SES. In this study they have found that if a student has an internet at home then he will aspire to a university, to pursue higher education he should be encouraged by teachers. The edifying level of the begetters', particularly the female begetter's education is more important to influence students than the encouragement of teachers'. It was discovered that for the aspiration of students the civilized and economic variables occupy an essential task and the predictive power of them to attend university increase significantly.

Zhao et. Al, (2011) found for China the SES of institution and the economic position of fellow citizens. Although the edifying level, progenitors profession and family economic level are used mostly whereas the SES indicators differ. Progenitors belonging to low SES are meagerly connected with their juvenile's institution and boost them meagerly in contrast to progenitors belonging to higher SES. Khajehpour \& Ghazvini (2011) found in the study of Toronto, Canada that children's school performance is influenced by parental involvement. Compassionate procreators are implicated by their juvenile's' academic projects and also assess them. These children respond positively to extracurricular activities and their school performance boost. In early stages of development, many families send their female descendants to work inspite of achieving knowledge so they could pay compensation for their male descendants' edification.

Sheehan (2012) found that expenditures on education have a significant effect on education outcomes. Mirashrafi (2013) found for Iran that large effects of parental education; parental job and the SES of family have been observed on entrance examination grades and on the result of university and college acceptance. Female grades increase marginally at all higher parental education levels and increased substantially for applicants with university educated parents. Sipahimalani (1999) found for India that by increasing household income by 1 percent the probability of girl's enrollment enhances from $9 \%$ to $13 \%$, whereas the probability of boy's enrollment enhances by $7 \%$ in school.

In case of Pakistan there is a vast literature on education system, access to basic education and gender based education. For example a piece of research was organized by Khan and Shah (2002) in which they found the issues allied with the accomplishment of knowledge of grade five learners in government schools. Their conclusion indicates that father's education significantly affects the student's achievement scores especially in the urban areas. It was further found that education of mother shows significant increase in urban areas on girl's 
achievement upto Secondary School Certificate level. Sandhu and Chaudry (2005) found that factors which are allied with the female development in rural districts of Faisalabad are "revenue, academic level of parents and occupation of the respondents". Revenue and edification of the respondent families and the maximum level of training that their female juveniles had acquired are associated with each other. Hijazi and Naqvi (2006) established that mother's erudition is significantly positively related and mother's age is considerably negatively related to learner's accomplishment respectively. The survey further specified that in case of Pakistan serious contradictory relationship of income on learner's effort was scrutinized.

The causes of SES on student's victory in Pakistan were observed in the study of Saifi and Mehmood (2011). The indicators of SES used by them were revenue, progenators'civilization and career, material acquired at residence, conveyance and domestic helpers. The findings indicated that the student's achievement was affected by progenitor's erudition and career and amenities at their dwelling. Hashmi, Zafar and Ahmad (2008) found momentous and favorable providers for the edifying accomplishment of the females exist in the rural areas of Jhang are "advanced instruction of parents, distances of institutions, improved inhabited and assets position of the households, gender favoritism attitude of the head of the households (HH) towards children's development, pioneering attitude of $\mathrm{HH}$ towards female inhabitants and recognition of the $\mathrm{HH}$ for advanced level of edification for females". Akhtar (2012) conducted a study in four districts of Rawalpindi Division. She found that the factors which positively affect the achievement of students are "mother's indoctrination, wages, refrigerator, and sources used to carry them to institution" whereas the "number of siblings and conveyance facility (car/van") negatively affect the achievement of students.

\section{MODEL SPECIFICATION}

\subsection{Assessment of Education Equality Index}

In this study we have used EEI along with pseudo panel technique for generalizing gender equality and factor influencing it in 14 major cities of Pakistan. The gender equality index is estimated by using the approach presented in Human Development Report.

In most of the reviews HDI or GDI is used but we have used a part of GDI i.e. EEI because this study is concerned with gender equality in education only. According to Human Development Report education index measures a country's relative achievement in both adult literacy and combined primary, secondary and tertiary education. For male and female an index for adult literacy and education attainment are computed individually. Then these two indices are pooled to generate the overall education index.

The education attainment ${ }^{4}$ is defined as:

Male education attainment $(M E A)=1$ if education attained by any individual male is $>0$

Female education attainment $(F E A)=1$ if education attained by any individual female is $>0$

While Adult Literacy is defined as:

Male Adult Literacy Index $(M A L I)=1$ if any individual male can read or write

Female Adult Literacy Index $(F A L I)=1$ if any individual female can read or write

Male and Femle indices are then calculated as:

Male education index $(M E I)=2 / 3 *(M A L I)+1 / 3 *(M E A)$

Female education index $(F E I)=2 / 3 *(F A L I))+1 / 3 *(F E A)$

Where:

1)MALI and FALI is Adult Literacy Index of male and female respectively. It is defined as "the population aged 15 - 65 that can read and write in any language divided by the total population aged 15 - 65 years multiplied by 100 ".

2)MEA and FEA is Education attainment index of male and female respectively. It is defined as "the persons who have completed their education divided by the population who should have completed their education".

The male and female indices in each dimension are combined to create Equally Distributed Education Index.

Equally Distributed Education Index $(E E I)=\left\{[M P S](M E I)^{-1}+[F P S](F E I)^{-1}\right\}^{-1}$

Where:

- MPS and FPS is the population share of male and female respectively.

- MEI and FEI is the education index of male and female respectively.

If EEI is $=1$ then education is equally distributed

If EEI is $<1$ then education is not equally distributed

\subsection{Determinants of Education Equality Index}

\footnotetext{
${ }^{4}$ Education attainment index has been estimated instead of enrollment because further in this study effect of education attainment index on female labor force has to be estimated for the age group 15-65. In this cohort most of the females would have acquired their education or have been illiterate
} 
After discussing the measurement of the gender equality through EEI we will now present the relationship between EEI and socioeconomic factors. The specific form of the model of gender equality at different levels of education tested is:

$$
\begin{aligned}
& E E I=f\left(H S I Z E_{C, T}, M S_{C, T}, C H_{C, T}, A D R_{C, T}, A M Y E D U_{C, T}, M H_{C, T}, A M H E D U_{C, T},\right. \\
& \left.D R W_{C, T}, G A S_{C, T}, E L E C_{C, T}, H I N C_{C, T}\right)
\end{aligned}
$$

Where $\mathrm{C}$ and $\mathrm{T}$ represent City and Time respectively.

EEI

is the equally distributed education index.

HSIZE

is the household size

MS

is the marital status of women. (Married or Single)

CH

is the children in a household under 15 years.

ADR

is the adult dependency ratio

AMYEDU

is the average years of mother education

MH

is the male head of the household.

MHEDU

is the education of the male head of a household

DRW

is the source of drinking water.

GAS

is the source of cooking.

ELEC

is the source of lightning.

HINC

is the level of household income. It could be the main factors, influencing parent's decision to invest in their children's human capital.

HSIZE is defined as "the number of persons living together in one house". It may positively or negatively relate to the education index. If the family size increases then parents invest less on education of their children especially girls due to low per capita income or high dependency ratio or both. However raise in household size results in raise in number of earners then per capita income of a family will be high therefore the opportunity to complete desired education of both genders will be improved.

The effect of marital status of the female on EEI may be affirmative or negative depending upon the status of women. EEI will increase for a single woman as she does not have any responsibilities, so she can achieve her desired education. Whereas a married family have household responsibilities, have to look after her children and in some cases are not allowed by their spouses to complete her education therefore EEI decreases.

$\mathrm{CH}$ is negatively related to EEI. As the number of children increases EEI will decrease. Adult female have to stay at home to look after her sibling's inspite of obtaining education.

ADR is positively related to EEI because older people know the importance of education therefore they will encourage the adults especially girls in a family to achieve their desired education.

AMYEDU is the main factor which influence EEI since a mother plays an imperative character in the life of her offsprings. An educated mother knows the significance of education so she also educates her children and has greater affect in household decision making which may permit her to secure more possessions for her children. The study hypothesizes that as mother's years of education increases EEI will also increase.

In our society most of the decisions are taken by the head of the household. It will be positively related to EEI because people in urban areas know the importance of education therefore household head will encourage adults especially girls to complete their education.Physical facilities show the household well being. If physical facilities are available then family members can concentrate on their studies hence education index will increase in a city.

Further study hypothesizes that as income increases household will spend more on education either male or female. Hence EEI will increase and vice versa. 


\section{DATA SOURCES}

To scrutinize the influence of gender equality in education for major cities of Pakistan the present research pooled cross section data of PSLM for the time span of 2004-2005 to 2012-2013. The Sampling technique and questionnaire of PSLM has gone through many changes since its inception for example after 2004-05 PSLM is reporting district wise data. However, for the year 2005-06 and 2007-08 the district level data are not available. For these two periods the sampling covers 14 large cities, Urban Divisions and Rural District. As the assessment is based on major urbanizing areas of Pakistan (large cities) the estimation remains unaffected by the changes. Another limitation that study faced using the PSLM data is that the data sets consist of repeated cross sections since each year different households are surveyed. To overcome the limitations Pseudo Panel technique is applied here.

\section{ECONOMETRIC METHODOLOGY}

The estimation of pseudo panel is conducted using fixed effect (FE) technique

\section{i. Pseudo Panel Technique}

As stated before Cross section data of PSLM for the years 2004-05, 2005-06, 2006-07, 2007-08, 200809, 2010-11,2011-12 and 2012-13 are pooled for the estimation. The Pseudo panel is used since it has the capacity to explain the past characteristics while simultaneously predicting the future behavior as compared to the simple cross section data. Further to this in a pseudo panel number of individual or household covered and the time period spanned are large over the repeated cross section. However, non-availability of individual histories usually requires for constructing instruments or for transforming a model to first differences is absent from the data. Panel data requires the assessment for the influence of gender equality in education. Individuals or households that can be traced back over time in order to explore the changes in average wages of a household, facilities available in house, education of mother and male head of household etc. would be useful in getting the historical perspective about the education. This is the only restriction study faced.

Nonexistence of large panel datasets, large cross section data sets replicated over time can be applied to create pseudo panels or synthetic cohorts as recommended by Deaton (1985) to estimate returns under certain postulations that organize for unobserved individual specific effects including those such as ability and motivation. Pseudo panels are typically created from a time series of independent surveys conducted under the same methodology on the same reference population but in different time periods such as labour force and household surveys that can be found in many developing countries. However, Deaton (1985) found that pseudo panels do not endure attrition problem that genuine panels have, and are usually available over longer time periods as compared to genuine panels. Deaton (1985) introduce the use of cohort i.e. estimating the empirical relationships by using some common characteristics like sex, date of birth, region etc shared by the group of individuals, known as cohort. This technique also helps in reducing the problem of heterogeneity that usually arises in cross sectional data. Following Deaton the study also applied pseudo panel technique using cities and female in age group 15-65 as cohorts.

In order to estimate study starts by consider following simple model $Y_{i t}=\alpha_{i}+\beta X_{i t}+\varepsilon_{i t} \quad t=1 \ldots . T$

Where " $X_{\text {it }}$ is a $(K \times 1)$ vector of explanatory variables" which is assumed to be exogenous, $\mathrm{i}$ is an index of individuals and $t$ is the time periods. Since same households are not the part of the sample every year therefore true panel is not available to analyze the above equation. By using Deaton (1985) technique cohorts C based on the city are identified, such that each individual $i$ is a member of one and only one cohort for each $t$. Averaging over the cohorts gives:

$\bar{y}_{c t}=\bar{\alpha}_{c t}+\beta \bar{x}_{c t}+\varepsilon_{c t} \quad C=1 \ldots . C$

It is supposed that the size of the group $\mathrm{c}$ at time $\mathrm{t}$ is $\mathrm{n}_{\mathrm{ct}}$ such that the mean value of all observed $\mathrm{X}_{\mathrm{it}}$ 's in the cohort $\mathrm{c}$ at time $\mathrm{t}$ can be given as:

$\overline{x_{c t}}=n_{c t}^{-1} \sum_{i \in c}^{s=t} x_{i s}$

Over $\mathrm{T}$ periods and $\mathrm{C}$ cohorts this data is a pseudo panel of iterated observations.

\section{ii Fixed Effect Technique ${ }^{5}$ :}

\begin{tabular}{lll}
${ }^{5}$ The data does not have an endogenity problem as it has been checked through Hausman test. \\
\hline DOI: $10.9790 / 0837-2109091425$ & www.iosrjournals.org & 20 | Page
\end{tabular}


Deaton (1985) recommended the use of FE model to estimate the pseudo panel. The sample average presents a reliable estimator of the time-invariant inhabitants mean when the sizes of cohorts are large. The larger $\mathrm{n}_{\mathrm{c}}$, means the errors-in-variables dilemma caused by probable time discrepancy in $\bar{\alpha}_{c t}$ is ignorable and standard estimators like the FE (within) estimators can be used.Our research falls into this category as well because the standard cohort size is reasonably substantial. Therefore, relationship among the determinants is estimated by the standard FE estimator on the cohort means that eliminates any unobserved differences between individual cohorts.In most empirical studies of economics the purpose is to explain the relationship between dependent variable, $\mathrm{Y}$, and one or more explanatory variables $\left(\mathrm{X}_{1}, \mathrm{X}_{2}, \ldots \mathrm{X}_{\mathrm{k}}\right)$. If $\mathrm{X}_{\mathrm{i}}$ influences on $\mathrm{Y}$, then direction and size of the effect should be known. To attain an unbiased reckon, observable and unobservable confounding variables are required to be restricted. A multiple classical linear regression model is used to organize for recognizable confounding variables.

A FE regression model is used to organize unobservable confounding variables that vary across units, but is time invariant. The FE regression model is an annex of the multiple classical linear regression models. However, for using a fixed regression model, panel (longitudinal) data is required.

The equation given below is fixed effect model (FEM) and is represented as:

$Y_{i t}=\beta_{1 i}+\beta_{2} X_{i t}+\beta_{3} X_{3 i t}+u_{i t}$

Where the subscript $i$ refer to different individuals and $t$ refers to different gauges within individuals, i.e. the same variable evaluated at different points in time.It is time invariant because intercept may differ across individuals and each individual's intercept does not vary over time. By applying the FE techniques it is possible to organize for all probable features of the entities even without calculating approximately them so long as those features do not modify over time. By applying ordinary least squares linear regression the FE techniques can easily be implemented if the dependent variable is quantitative. To controls for the FE model all time-invariant dissimilarities between the characters, evaluates the coefficients of the FE models which are not inclined because of excluded time-invariant characteristic (like customs, religion, gender, race, etc)

The affiliation between analyst and consequence variables is investigated by FE within an entity. Individual characteristics of each entity might or might not manipulate the predictor variables. It is implicated that something within the entity may influence or discriminate the forecasted variables and it is needed to be controlled by using FE. The conjecture behind this validation is the correspondence between individual's inaccuracy and forecast variables. FE eradicates the consequence of those times invariant characteristics that can be appraised by the net consequence of the predictors on the outcome variable.

Overall 112 observations of 14 urban cities are selected from the eight cross section data periods. The pseudo panel is constructed by computing cohorts/cells average for each available cross section, where the cells are defined as city codes for the female age 15-65. After making pseudo panel FE regression model is applied to analyze the determinant of gender equality.

\subsection{Changes in Gender Equality by City and Time}

\section{RESULTS AND DISCUSSION}

Change in gender equality of education by time and city is discussed in table 3 .

Table 3: Education Equality Index by Time and City (16 years of Education)

\begin{tabular}{|l|l|l|l|}
\hline City & $\mathbf{2 0 0 4 - 0 5}$ & $\mathbf{2 0 1 2 - 1 3}$ & Change (in \%) \\
\hline Islamabad & 0.886 & 0.905 & 2.144 \\
\hline Rawalpindi & 0.825 & 0.850 & 3.030 \\
\hline Sargodha & 0.766 & 0.820 & 7.049 \\
\hline Faisalabad & 0.775 & 0.859 & 10.839 \\
\hline Gujranwala & 0.787 & 0.853 & 8.386 \\
\hline Sialkot & 0.838 & 0.883 & 5.369 \\
\hline Lahore & 0.798 & 0.828 & 3.759 \\
\hline Multan & 0.625 & 0.785 & 25.6 \\
\hline Bahawalpur & 0.727 & 0.818 & 12.517 \\
\hline Sukkur & 0.736 & 0.762 & 3.533 \\
\hline Hyderabad & 0.683 & 0.798 & 16.837 \\
\hline Karachi & 0.833 & 0.875 & 5.042 \\
\hline Peshawar & 0.634 & 0.641 & 1.104 \\
\hline Quetta & 0.697 & 0.703 & 0.8608 \\
\hline
\end{tabular}


From table 3 it can be analyzed that gender parity in education has increased which is a good sign for the prosperity of our country. It has increased sharply in Faisalabad, Hyderabad, Multan and Bahawalpur whereas it has increased slowly in Quetta.

Summary statistics of 16 years of education, Secondary education and Higher education are discussed in table 4. Secondary Education ranges from Class 9 to Class 12 i.e. (SSc and HSc) whereas Higher education includes Graduation, Post graduation and M. Phil /Ph D

Table 4: Education Equality Index at Different Education Levels

\begin{tabular}{|l|l|l|l|}
\hline Variable & Range & Median & Standard Deviation (SD) \\
\hline $\begin{array}{l}\text { Education Equality Index for 16 } \\
\text { years of Education( EEI) }\end{array}$ & 0.372 & 0.789 & 0.082 \\
\hline $\begin{array}{l}\text { Secondary Education Equality Index } \\
\text { (SEEI) }\end{array}$ & 0.351 & 0.646 & 0.075 \\
\hline $\begin{array}{l}\text { Higher Education Equality Index } \\
\text { (HEEI) }\end{array}$ & 0.396 & 0.569 & 0.077 \\
\hline
\end{tabular}

\subsection{Determinants of Gender Equality in Education ${ }^{6}$}

As explained earlier FE technique ${ }^{7}$ is used to explore the determinants of gender equality. This section is based on the estimation of equation 1. Table 5 presents the outcomes. The result demonstrates that household size has a momentous and affirmative effect on gender equality upto 16 years of education. The result illustrates that $1 \%$ raise in the HSIZE increases the gender equality in education by $2 \%$.

Married female in a city also has significant and negative effect on gender equality upto 16 years of education. As the married females increase in a city then gender equality in education will decrease. The increase of married females in the city by $1 \%$ will decrease the gender equality in education equality by $83 \%$.

Table 5: Determinants of Gender Equality in Education at different levels of Education

\begin{tabular}{|c|c|c|c|}
\hline Variables & $\begin{array}{l}\text { Coefficients of } 16 \\
\text { Years of Education }\end{array}$ & $\begin{array}{ll}\text { Coefficients } & \text { of } \\
\text { Secondary } & \\
\text { Education } & \\
\end{array}$ & $\begin{array}{ll}\text { Coefficients } & \text { of } \\
\text { Higher Education } & \end{array}$ \\
\hline Household size (HSIZE) & $\begin{array}{l}0.020^{* * * *} \\
(1.91)\end{array}$ & $\begin{array}{l}0.003 \\
(0.37) \\
\end{array}$ & $\begin{array}{l}0.008 \\
(0.89)\end{array}$ \\
\hline Married Female (MS) & $\begin{array}{l}-0.831^{* * *} \\
(-1.74)\end{array}$ & $\begin{array}{l}-0.657^{* * *} \\
(-1.69)\end{array}$ & $\begin{array}{l}-0.711^{* \cdots *} \\
(-1.79)\end{array}$ \\
\hline Single Female (MS) & $\begin{array}{l}-0.625 \\
(-1.18)\end{array}$ & $\begin{array}{l}-0.404 \\
(-0.94)\end{array}$ & $\begin{array}{l}-0.629 \\
(-1.43)\end{array}$ \\
\hline $\begin{array}{l}\text { Children under } 15 \text { years } \\
(\mathrm{CH})\end{array}$ & $\begin{array}{l}-2 \mathrm{E}-04 \\
(-1.28) \\
\end{array}$ & $\begin{array}{l}-2.64 \mathrm{E}-04^{* *} \\
(-2.66)\end{array}$ & $\begin{array}{l}-3.65 \mathrm{E}-04^{*} \\
(-3.57)\end{array}$ \\
\hline $\begin{array}{l}\text { Adult Dependency ratio } \\
\text { (ADR) }\end{array}$ & $\begin{array}{l}0.002 \\
(0.43)\end{array}$ & $\begin{array}{l}0.002 \\
(0.49)\end{array}$ & $\begin{array}{l}0.007 \\
(1.91)\end{array}$ \\
\hline $\begin{array}{l}\text { Average mother years of } \\
\text { education (AMYEDU) }\end{array}$ & $\begin{array}{l}0.010^{* * *} \\
(2.00) \\
\end{array}$ & $\begin{array}{l}0.007^{\text {***k }} \\
(1.73) \\
\end{array}$ & $\begin{array}{l}0.015^{* * *} \\
(3.54)\end{array}$ \\
\hline $\begin{array}{l}\text { Male head of household } \\
(\mathrm{MH})\end{array}$ & $\begin{array}{l}-9.07 \mathrm{E}-06 \\
(-0.08)\end{array}$ & $\begin{array}{l}-1.15 \mathrm{E}-04 \\
(-1.27)\end{array}$ & $\begin{array}{l}-6.4 \mathrm{E}-05 \\
(-0.69)\end{array}$ \\
\hline $\begin{array}{l}\text { Education of Male head of } \\
\text { household (AMHEDU) }\end{array}$ & $\begin{array}{l}0.052^{*} \\
(2.70) \\
\end{array}$ & $\begin{array}{l}0.047^{*} \\
(3.03)\end{array}$ & $\begin{array}{l}0.065^{*} \\
(4.03)\end{array}$ \\
\hline Drinking water (DRW) & $\begin{array}{l}-5.77 \mathrm{E}-06 \\
(-1.63) \\
\end{array}$ & $\begin{array}{l}-5.90 \mathrm{E}-06^{* *} \\
(-2.05)\end{array}$ & $\begin{array}{l}-1.90 \mathrm{E}-06 \\
(-0.64) \\
\end{array}$ \\
\hline Gas used for cooking & $\begin{array}{l}8.19 \mathrm{E}-05^{*} \\
(-2.69)\end{array}$ & $\begin{array}{l}5.87 \mathrm{E}-05^{* *} \\
(2.38)\end{array}$ & $\begin{array}{l}7.61 \mathrm{E}-05^{*} \\
(3.00)\end{array}$ \\
\hline
\end{tabular}

\footnotetext{
${ }^{6}$ Education Equality Index for Primary education is not discussed in this study because in major cities education attainment of girls at primary level is higher as compared to secondary and higher.
}

${ }^{7}$ Number of years has been fixed to explore the determinants of Gender Equality in Education.

DOI: 10.9790/0837-2109091425 www.iosrjournals.org 22 |Page


Gender Equality in Education: Case of MajorUrbanizing Areas of Pakistan

\begin{tabular}{|l|l|l|l|}
\hline $\begin{array}{l}\text { Electricity used for } \\
\text { lightning (ELEC) }\end{array}$ & $\begin{array}{l}-5.42 \mathrm{E}-05^{* *} \\
(-2.45)\end{array}$ & $\begin{array}{l}-4.69 \mathrm{E}-07 \\
(-0.03)\end{array}$ & $\begin{array}{l}-1.4 \mathrm{E}-05 \\
(-0.76)\end{array}$ \\
\hline $\begin{array}{l}\text { Household Income } \\
\text { (HINC) }\end{array}$ & $\begin{array}{l}0.020^{* * *} \\
(1.84)\end{array}$ & $\begin{array}{l}0.019^{* *} \\
(2.21)\end{array}$ & 0.013 \\
& & $(1.39)$ \\
\hline Constant & $0.945^{* * *}$ & $0.770^{* * *}$ & $0.870^{* * *}$ \\
& $(1.82)$ & $(1.83)$ & $(2.02)$ \\
\hline $\mathrm{R}^{2}$ within & 0.435 & 0.519 & 0.635 \\
\hline $\mathrm{R}^{2}$ between & 0.204 & 0.487 & 0.705 \\
\hline $\mathrm{R}^{2}$ overall & 0.284 & 0.479 & 0.668 \\
\hline F- statistics (12,72) & $4.62(0.000)^{*}$ & $6.48(0.000)^{*}$ & $10.46(0.000)^{*}$ \\
\hline
\end{tabular}

Note: $*, * *, * * *$ Significant at $1 \%, 5 \%$ and $10 \%$ respectively. The values in the parentheses represent the $\mathrm{t}$ values.

Average years of mother education show a favorable and noteworthy impact on gender equality upto 16 years of education. We hypothesize that an educated mother knows the benefits of education so she will take special care to educate her children especially girls. Moreover, an educated mother's has an immense affect in domestic negotiations which may permit her to secure more resources for her children. The result confirms our hypothesis. The result shows that $1 \%$ increase in the AMYEDU will increase the gender equality in education by $1.008 \%$.Education of the Male head of the household has an affirmative and vital impact on gender equality upto 16 years of education as most of the decisions of the house are taken by the head of the household in our society so an educated male always encourage his household members to achieve their desired education especially female as he will know the value of education. The result shows that $1 \%$ raise in the AMHEDU will enhance the gender equality in education by $5.2 \%$.

Availability of gas used for cooking is used here as an indicator of household well-being. It shows positive and slightly considerable effect on gender equality in education. Electricity used for lighting shows negative and slightly considerable effect on gender equality upto 16 years of education.

Positive and trivial significant impact of household income on gender equality upto 16 years of education has also been observed i.e. the increase in household income will diminish the gender gap in education. The result shows that $1 \%$ increase in HINC will increase the gender equality by $2.02 \%$.

Unfavorable and significant effect of Children less than 15 years has been observed on gender equality in secondary education. As the number of children increases gender equality in secondary education of adult female will decrease. Since adult female will be forced to stay at home and look after her siblings rather than achieving her desired education. Precisely $1 \%$ increase in the children age below 15 will decrease gender equality in secondary education by $0.03 \%$. Married female and Drinking water have negative and momentous effect on gender equality in secondary education. Whereas positive and significant effect of AMYEDU, AMHEDU, GAS and HINC has been observed on gender equality in secondary education from table 5 .

Gender equality in higher education has unfavorable and critical effect on married female and CH.AMYEDU, AMHEDU and GAS have positive and significant effect on gender equality in higher education.

\section{CONCLUSION AND POLICY RECOMMENDATIONS}

The results of this study are based on the effect of gender equality upto 16 years of education. Results indicate that Gender equality upto 16 years of education has increased in almost all the cities but it has shown development especially in Faisalabad, Multan, Hyderabad and Bahawalpur.

The study is based on the results which infer that by increasing the education of mother and male head of the household, positive and significant impact on gender equality in education attainment of male and female adults is observed. As mother plays a fundamental character in the life of her offspring so a sophisticated mother will educate her offspring. An educated mother will participate in decisions made by the household for the betterment of her children. She will take better care of her child's health and education. If an educated mother is also in labor force then she could give good advice to her children for their higher studies and will encourage them to achieve their desired education. Being a male dominated society most of the decisions are taken by the male head of the household, but now traditions of our society are changing especially in urban areas, besides male female is also involved in household decisions especially in the education of her children. An educated male knows the benefits of education especially female education. Therefore female education is boosting especially in urbanizing areas of Pakistan.Among the determinants; increase in the household size increases gender equality in education by $2 \%$ whereas the number of married female increases gender equality upto 16 
years of education will decrease by $83 \%$. Average years of mother education and education of the male head of the household increase the gender equality in education by $1.008 \%$ and $5.2 \%$ respectively.

Moreover, married female has a crucial and unfavorable effect on gender equality as married female has household responsibilities so rather than completing her desired education she has to look after household chores and raise her children.

Household well being plays an imperative role in increasing or decreasing gender equality upto 16 years of education. Availability of physical facilities in a house will increase gender equality in education and its shortage or non availability will decrease gender equality in education.

Household income has affirmative and noteworthy effect on gender equality in education. Families with high income/average income give desired education to their children especially girls or the child who is taking interest in his/her studies. Therefore gender gap is reducing rather than widening.

From this study it is suggested that the investment in female education increases the opportunities of child's education in future. Hence female education should be the central focus to acquire education attainment. By educating a female a generation is educated therefore educated mothers can educate and train their children to play a positive role in a society as high quality individuals.

From this study it is suggested that the investment in female education increases the opportunities of her offsprings' education in future. Hence mothers/female education should be the central focus to acquire education attainment. Education and training can be given to offspring by their Mothers who can play a constructive role in a society as admirable individuals.

It is recommended that parents should give desired education to their children especially girls instead of getting them married. As female will marry late she will keep her family small and will concentrate more towards her offspring's health and education. By educating a female a generation can be educated.

Strategy and agenda of adult education can be managed to roll out in all parts of the state especially in undeveloped areas of cities. Adult's education significance can be envisaged by supporting to strengthen attitudinal modification among uninformed and uncomprehend progenitors in support of their descendants' edification. The government should increase the public institutes and make 16 years of education compulsory for all citizens and also lower its cost.

\section{REFERENCES:}

[1] Al-Qudsi S., Sulayman (2003), "Family background, school enrolments and wastage: evidence from Arab countries". Economics of Education Review, Vol: 22 (6): pp: 567-80.

[2] Bowden, M. P and Doughney, J (2011), "The importance of cultural and economic influences behind the decision to attend higher education", The Journal of Socio- Economics, Vol: 41, pp: 95-103

[3] Deaton, A. (1985), "Panel data from time series of cross-sections", Journal of Econometrics, Vol: 30, No. 1-2, pp: 109-126.

[4] Engir-Demir, C (2009), "Factors influencing the academic achievement of the Turkish urban poor", International Journal of Educational Development, Vol: 29, pp: 17-29

[5] Gudlaug Erlendsdóttir (2010), "Effects of parental involvement in education. A case study in Namibia M.Ed. thesis", Faculty of Education Studies, University of Iceland.

[6] Hijazi, T. \& Naqvi, R. (2006), "Factors effecting student's performance: A case of private colleges", Bangladesh e-Journal of Sociology. Vol: 3(1), pp: 1-10

[7] Holmes, J. (2003), "Measuring the determinants of school completion in Pakistan: Analysis of censoring and selection bias". Economics of Education Review, Vol: 22, pp: 249-264

[8] Jennifer (2005) cited in Mihala Teodor (2012), "The Influence of socio economic status on School Perforance", .Romania journal of experimental applied psychology Vol: 3(2)

[9] Kevin Shaheen (2012), "Does Gender Inequality in Education affect Education Outcomes"? Springer Journal pp: 5-6.

[10] Khajehpour, M., Ghazvini, S. D, (2011), "The role of the parental involvement affect in Ma, X., (2001). Stability of socio-economic gaps in mathematics and science achievement performance", report, Toronto Star (1987), Toronto, Canada

[11] Knodel, John. (1997). "The Closing of the Gender Gap in Schooling: The Case of Thailand", Comparative Education

[12] Lochner, L. \& Belley, P. (2008), "Educational attainment by parental income: a Canada U.S. comparison", The Boston University Econometrics Seminar, November 2008.

[13] Naimatullah Hashmi, Muhammad Iqbal Zafar and Munir Ahmad (2008), "Cultural determinants of Female education attainment in rural Jhang, Punjab, Pakistan", Pakistan Journal of Agriculture Science, Vol: 45(1).

[14] Saifi, S. \& Mehmood, T. (2011), "Effects of socio-economic status on student's achievement", International Journal of Social Sciences and Education, Vol: 1(2), pp: 119-128. 
[15] Schnabel (2002)," Parental Influence on Students' Educational Choices in the United States and Germany: Different Ramifications-Same Effect'? , Journal of Vocational Behavior Vol: 60, pp: 178198

[16] Schultz, Paul (1999), "Health and schooling investments in Africa", Journal of Economic Perspectives, Vol: 13 (3), pp: 67-88.

[17] Seyed Bagher Mirashrafi (2013), "The Effect of Family Background and Socioeconomic Status on Academic Performance of Higher Education", Applicants International Journal of Technology and Inclusive Education (IJTIE), Vol: 2

[18] Shah, D. \& Khan, H. (2002), "Factors associated with learning achievement of grade-V students in public schools", AEPAM Research Study No: 167

[19] Sipahimalani (1999) cited in Sundaram, Aparna. (2000) "Gender Differentials in Literacy in India," Thesis, University of Maryland

[20] Sundaram, Aparna. (2000), "Gender Differentials in Literacy in India," Thesis, University of Maryland

[21] Tansel, Aysit (2003), "Determinants of school attainment of boys and girls in Turkey:, individual, household and community factors", Economics of Education Review, Vol: 21 (5), pp : 455-70.

[22] Tauqir Asandhu and Ayesha Chaudhry (2005)," Effects of Socioeconomic factors on the Female Education in Rural Areas of Faisalabad, Pakistan", Journal of Agricultural and Social Science.

[23] Wolter Hassink and Hannah Kiiver (2007), "Age-dependent Effects of Socio-economic Background on Educational Attainment - Evidence from Germany”, Utrecht School of Economics Tjalling C. Koopmans Research Institute Discussion Paper Series No: 07-26

[24] Zarina Akhtar (2012), "Socio Economic Status Factors Effecting the Students Achievement: A Predictive Study", International Journal of Social Science and Education, Vol: 2.

[25] Zhao, N., Valcke, M., Desoete, A and Verhaeghe, J (2011), "The quadratic relationship between socioeconomic status and learning performance in China by multilevel analysis: Implications for policies to foster education equity", International Journal of Educational Development. 